\title{
MEDIA ONLINE DAN KERJA DIGITAL PUBLIC RELATIONS POLITIK PEMERINTAH PROVINSI DKI JAKARTA
}

\author{
Asep Bidin Rosidin ${ }^{1}$ dan Abdul Hamid ${ }^{2 *}$ \\ ${ }^{1,2}$ Pascasarjana Universitas Paramadina Jakarta \\ *abdulhamidtalks@gmail.com
}

\begin{abstract}
Political public relations plays a strategic role in producing and distributing information to the public. Not only that, the ideal must arrive at the level of being able to create solidity and cohesiveness on all fronts. Along with the development of the times, political public relations is required to be adaptive, collaborative and flexible. To fulfill these three aspects, political public realtions must master the use of new media in order to support their work. This research focuses on the study of how political public relations uses new media as a means of supporting the delivery of information. The purpose of this research is to know how the implementation of the use of online media by political public relations within the DKI Jakarta Provincial Government. The research method used by the author is a qualitative method in which data can be obtained through observation and interviews. From observations and interviews, this research results in the fact that political public relations has utilized new media to disseminate information quickly and thoroughly according to the characteristics of new media that can be accessed globally and efficiently.
\end{abstract}

Keywords: new media; political public relations; media relations; pemprov dki jakarta

\begin{abstract}
Abstrak
Public relations politik memegang peran strategis untuk memproduksi dan mendistribusikan informasi ke masyarakat. Tidak hanya itu, idealanya harus sampai pada tataran mampu menciptakan soliditas dan kohesivitas semua lini. Seiring berkembangnya zaman, public relation politik dituntut untuk adaptif, kolaboratif dan fleksibel, untuk memenuhi tiga aspek tersebut, public realtions politik harus menguasai penggunaan new media agar dapat menunjang pekerjaannya. Penelitian ini berfokus pada kajian tentang bagaimana public relations politik menggunakan new media sebagai sarana penunjang penyampaian informasi. Tujuan penelitian ini adalah ingin mengetahui bagaimana implementasi penggunaan media online oleh public relations politik di lingkungan Pemprov DKI Jakarta. Metode penelitian yang digunakan oleh penulis adalah metode kualitatif yang datanya di dapat melalui observasi dan wawancara. Dari observasi dan wawancara, penelitian ini menghasilkan fakta bahwa public relations politik telah memanfaatkan media baru untuk menyebarkan informasi dengan cepat dan menyeluruh sesuai karakteristik media baru yang dapat diakses secara global dan efisien.
\end{abstract}

Kata kunci: Media Baru, Public Relations Politik, Media Relation, Pemprov DKI Jakarta

\section{PENDAHULUAN}

Media online lahir di era teknologi informasi yang berkembang sangat pesat, dengan dukungan internet sebagai basis penyebaran informasi, media online hadir sebagai pilihan baru untuk memenuhi kebutuhan informasi. Media baru merupakan generasi ketiga dalam komunikasi politik yang memungkinkan siapa pun menjadi produsen sekaligus konsumen informasi ((Heryanto, 2018:23). Media online sebagai generasi ketiga media massa juga digunakan oleh humas atau public relations di Pemerintah Provinsi DKI Jakarta. Dengan berbasis internet, humas Pemprov DKI Jakarta menyebarluaskan program-program, kebijakan serta informasi di lingkungan kerja Pemprov DKI Jakarta, informasi tersebut dimasukkan ke dalam portal 
jakarta.go.id, https://ppid.jakarta.go.id, dan diskominfotik.go.id. Salah satu media baru yang digunakan oleh public relations di Pemprov DKI Jakarta adalah Youtube.

Tiga generasi komunikasi politik, jika merujuk pada dinamikanya, antara lain: Generasi pertama, retorika politik. Hampir seluruh pesan komunikasi politik diarahkan oleh kemampuan seni berbicara (art of speech); Generasi kedua, ditandai dengan dominannya peran media massa yang belakangan kerap disebut sebagai media mainstream; Generasi ketiga, ditandai dengan perkembangan new media. Hal ini seiring dengan menguatnya sosial media, seperti situs jejaring sosial (social network site) dan weblog interaktif (Heryanto, 2018:24).

Media online adalah media massa "generasi ketiga" setelah media cetak (printed media) koran, tabloid, majalah, buku dan media elektronik (electronic media) radio, televisi, dan film/video. Media online merupakan produk jurnalistik online (Romli, 2012:15-16).

Kemajuan teknologi informasi telah membawa masyarakat masuk ke dalam abad informasi. Bahkan, berita dari negara-negara lain bisa dengan cepat dan mudah didapatkan. Komunikasi jarak jauh antarnegara atau benua pun bisa dilakukan dengan hadirnya internet yang disebut-sebut sebagai new media. New Media sendiri memiliki pengertian yaitu, teknologi berbasis komputer yang tidak hanya berfungsi untuk memberikan informasi tetapi juga berfungsi untuk saling tukar informasi, seperti komputer, internet, terminal video teks, kabel digital dan sebagainya (West \& Turner, 2008).

Sering perkembangan zaman, new media digunakan sebagai sarana komunikasi politik. Penyampaian program-program strategis pun kerap menggunakan new media karena memiliki karakter cepat dan efektif. Tidak terkecuali public relations politik di lingkungan Pemerintah Provinsi DKI Jakarta juga menggunakan media baru untuk memenuhi kebutuhan informasi masyarakat yang berkaitan tentang program kerja, kebijakan dan agenda di masa mendatang.
Political public relations is the management process by which an organization or individual actor for political purpose, through purposeful communication and action, seeks to influence and to establish, bulid, and maintain beneficial relationships and reputations with its key publics to help support its mission and achieveits goals (Strömbäck, 2011:8).

Didasari dari definisi Stromback \& Kiousis itu maka, secara sederhana public relations politik dapat diartikan sebagai proses manajemen suatu organisasi atau aktor-aktor politik yang juga terlibat di dalam organisasi atau individu lainnya demi mencapai tujuan politis, melalui sebuah persuasi di dalam komunikasi untuk memengaruhi dan membentuk, membangun dan menjaga hubungan yang saling menguntungkan satu sama lain untuk memperoleh penghargaan serta kepercayaan dari publik sebagai upaya mencapai visi misi dan sasaran yang telah ditentukan.

Dalam konteks ini media online dapat menjadi sarana penunjang kerja-kerja digital public relations politik khususnya di lingkungan Pemerintah Provinsi DKI Jakarta. Karena di era keterbukaan informasi Pemprov DKI dituntut dapat memberikan pelayanan informasi kepada publik secara cepat, mudah dan transparan. Di sisi lain public relations berperan sebagai dewan pertimbangan yang memberikan saran-saran serta pertimbangan kepada gubernur agar langkah-langkah yang diambil tepat dan cermat. Terlebih, saat ini posisi public relations berada pada zona strategis bidang komunikasi dan informasi publik dan keberadaanyapun menjadi penting sebagai pihak yang menjadi penghubung ke setiap stakholder terkait.

Ada empat hal utama yang mendorong perubahan dalam bidang public relations yaitu: (1) Globalisasi. Jangkauan pasar yang makin luas, terbuka, dan komunikasi langsung dengan khalayak dapat dilakukan dengan lebih mudah dengan adanya media. Karenanya, kemampuan komunikasi yang baik dengan lingkungan yang terus berubah sangat diperlukan. Sulit membayangkan jika sebuah organisasi yang 
ingin terus berkembang tidak menggunakan sentuhan public relations; (2) Banyaknya organisasi milik pemerintah yang mulai dikelola oleh swasta. Profesionalisme serta tujuan meraih keuntungan melalui manajemen modern dan teknik pemasaran dilakukan. Tentu saja, itu semua memerlukan kemampuan untuk melakukan komunikasi dengan lingkungannya; (3) Kehadiran internet yang membuka jalur komunikasi antara organisasi dan lingkungannya semakin terbuka. Saat ini, khalayak atau pihak-pihak yang berhubungan dengan suatu organisasi dapat langsung mengemukakan pendapat, keluhan, kritik, dan sarannya melalui internet. Organisasi tidak lagi mengabaikannya. Karenanya public relations harus tanggap dan dapat merespon dengan tepat. Lingkungan organisasi juga dapat bertambah karena internet membuka kesempatan pada berbagai pihak untuk berhubungan dengan organisasi; (4) Adanya pasar yang terbuka dan dukungan media menimbulkan berbagai isu di luar politik banyak berkembang saat ini, seperti isu lingkungan, kesehatan, budaya, dan lainnya. Berbagai aktivitas public relation diperlukan untuk hal tersebut agar organisasi tidak memperoleh dampak buruk dari beredarnya isu-isu resebut (Morris, T. dan Goldsworthy, 2008:175).

Penelitian ini didasari oleh ketertarikan penulis pada penggunaan media online atau new media dalam kerja digital public relations politik di lingkungan Pemerintah Provinsi DKI Jakarta sebagai salah satu dari empat faktor pendorong perubahan public relations yang saat ini pesan disampaikan tidak hanya melalui tatap muka tapi bisa dikomunikasikan dengan alat bantu komunikasi berupa media online. Pembentukan image positif dibentuk sedemikian rupa, baik dalam program-program kerja, pidato dan konferensi pers yang disebarluaskan melalui pemberitaan di media massa dan portal-portal informasi resmi milik Pemprov DKI.

Kemunculan internet sebagai new media berdampak pada perubahan cara kerja public relations yang dituntut tidak hanya komunikatif dan kreatif tetapi juga harus kreatif menggunakan lebih dari satu media untuk melaksanakan tugas-tugas kerjanya. Kemudian perubahan "pasar" yang terbuka dan sistem kerja yang dinamis, menjadikan public relations tidak hanya berkecimpung di satu isu saja, melainkan mampu memahami isu lain seperti sosial, hukum bahkan politik, public relations tidak bisa lagi digambarkan sebagai divisi yang bertugas menjaga citra positif perusahaan tetapi jauh dari itu, public relations telah berkembang sebagai divisi strategis di dalam organisasi, lembaga ataupun kantorkantor pemerintahan.

Konsep penelitian ini menggunakan Public relations atau yang juga disebut humas merupakan suatu profesi yang akrab dengan pembentukan image positif bagi korporasi dan identik dengan aktivitas-aktivitas bisnis nonkomersial dan komersial yang tentunya dapat memberikan keuntungan finansial bagi perusahaan. Public relations menjadi divisi strategis di sebuah perusahaan tidak terkecuali perusahaan-perusahaan dengan modal besar dan perusahaan kecil, hampir setiap korporasi memiliki humas sebagai divisi terdepan dalam pembentukan citra dan reputasi baik dimata publik atau perusahaan lainnya (Natawilaga, 2018) .

Public relations sesungguhnya merupakan aktivitas yang dibutuhkan oleh seluruh organisasi, baik komersial maupun nonkomersial. Public relations sejatinya merupakan aktivitas komunikasi untuk membangun good will (niat baik) dan pemahaman (understanding) dari pihak-pihak lain yang menjalin hubungan dengannya. Secara ilmiah ataupun secara praktis. Perbedaan yang cukup mencolok terkait tugas pokok dan fungsi public relations intansi pemerintah dan non intansi pemerintah terdapat pada tidak adanya unsur komersial bagi humas di intansi pemerintahan, karena meskipun melakukan publikasi yang berkaitan dengan jalannya pemerintahan namun humas di intansi pemerintah lebih berfokus pada pelayanan publik. Humas pemerintah khususnya Pemprov DKI berada di dalan satu unit kerja yang 
melaksanakan tugas-tugas publikasi, penyampaian informasi serta pelayanan kebutuhan publik.

Definisi public relations sebagai fungsi manajemen khusus yang membantu pembentukan dan pemeliharaan garis komunikasi dua arah, saling pengertian, saling menerima dan bekerjasama antara satu organisasi atau perusahaan dan masyarakat yang melibatkan manajemen masalah, membantu manajemen untuk selalu mendapat informasi dan merespons pendapat umum, mendefinisikan dan menekankan tanggung jawab manajemen dalam melayani kepentingan masyarakat, membantu manajemen untuk mengikuti dan memanfaatkan perubahan secara efektif, berfungsi sebagai peringatan awal untuk mengantisipasi kecenderungan dan menggunakan riset, serta komunikasi yang masuk akal dan etis sebagai sarana utamanya "Public Relations is the management function that establishes and maintains mutually beneficial relationship between an organization and ther publics on whom its succes or failure depends" (Cutlip, Scott M., 2000:6).

Konsep-konsep public relations memiliki kesamaan antara konsep satu dengan yang lainnya, yaitu: Pertama, public relations itu sendiri adalah fungsi manajemen; Kedua, public relations adalah manajemen komunikasi antara organisasi dan publiknya; Ketiga, hubungan antara organisasi dan publik; Keempat, hubungan antara organisasi dan publiknya tersebut bersifat mutually beneficial ((Rusfian, Effy \& Nuhajati, 2015:5-6).

Pada umumnya, politik dapat dikatakan sebagai bentuk dari kegiatan dalam suatu sistem politik (atau negara) yang terkait dengan proses menentukan tujuan-tujuan sekaligus cara melaksanakan tujuan-tujuan sistem tersebut. Dalam konteks ini, politik terkait dengan pengambilan keputusan (decision making) mengenai apakah yang menjadi tujuan dari sistem politik menyangkut seleksi antara beberapa alternatif dan penyusunan skala prioritas dari tujuan-tujuan yang telah dipilih (Budiarjo, 2005:8).
Pemahaman public relations politik sebagai berikut: (1) Public relations politik terkait dengan proses melayani publik internal dan publik eksternal dari sebuah institusi atau organisasi politik, seperti partai; (2) Public relations politik biasanya terkait dengan sejumlah isu dan dinamika khusus yang dikelola guna mendapatkan perhatian para pemilih (voters); (3) Public relations politik memiliki orientasi pada pengumpulan dukungan seluas mungkin terhadap khalayak melalui berbagai saluran yang bisa dimanfaatkan mulai saluran formal hingga saluran informal (Heryanto, \& Zarkasi, 2012).

Tujuan utama dari public relations dalam bidang politik adalah untuk menyajikan individu atau organisasi dalam tampilan yang positif, agar meningkatkan kunci persepi publik pada individu atau organisasi itu serta memungkinkan mengajak masyarakat untuk melakukan sesuatu bagi individu atau organisasi tersebut. Dalam hal ini public relations politik bisa di definisikan sebagai pekerjaan untuk menampilkan citra baik sekaligus mendapatkan dan memengaruhi publik (Lilleker, 2006)

Public relations politik merupakan ilmu terapan baru dalam bidang kajian public relations. Hal ini menjadi sebuah kajian yang penting dan menarik karena tiga faktor. Pertama, munculnya fenomena politik modern yang kian banyak memanfaatkan media massa, jasa konsultan dan taktik, serta strategi komunikasi politik. Kedua, majunya teknologi yang memungkinkan berbagai tindakan politik dilakukan tidak harus bertemu secara fisik. Misalnya, pendekatan new media (media online) dalam pelaksanaan komunikasi politik. Pendekatan komunikasi menjadi lebih dinamis, interaktif, dan serba cepat. Ketiga, munculnya era demokrasi yang memungkinkan semua warga negara untuk memperoleh kebebasan berkumpul dan mengeluarkan pendapat, baik lisan maupun tulisan.

Tujuan utama aktivitas public relations politik adalah mendapatkan dukungan politik dari publik internal ataupun eksternal dalam pencapaian tujuan khusus sebuah organisasi 
atau institusi politik. Tujuan utama ini jika dirinci lagi adalah sebagai berikut: (1) Menciptakan soliditas dan kohesivitas internal organisasi melalui upaya pelayanan publik internal, sehingga seluruh komponen dan sumber daya politik organisasi bisa dioptimalkan dalam pencapaian tujuan organisasi; (2) Menjembatani hubungan organisasi dengan publik eksternal dalam rangka menumbuhkan kesepahaman dan dukungan atas sejumlah program dan tujuan khusus organisasi; (3) Memperoleh penemuanpenemuan, penyimpulan-penyimpulan, dan rekomendasi atas sejumlah isu dan dinamika politik yang berkembang; (4) Mengetahui secara pasti posisi kekuatan, kelemahan, dan peluang, serta tantangan organisasi di tengah hubungannya dengan berbagai pihak di internal ataupun eksternal organisasi melalui evaluasi yang sistematis, terarah, dan berkelanjutan.

Dalam penelitian digunakan referensi penelitian terdahulu yang dilakukan oleh Cornelius Ardian Sukmaji Wicaksosno (2016) berjudul "Media Baru dalam Komunikasi Pemerintah Studi Kasus Penggunaan Media Baru untuk Pelayanan Informasi Publik Di Kementrian Perhubungan". Tujuan penelitiannya adalah untuk memahami bagaimana kementrian perhubungan menggunakan media baru, khususnya website dan media sosial sebagai sarana untuk mengkomunikasikan program pemerintah sekaligus sebagai wujud pelayanan informasi publik. Metode penelitian yang digunakan adalah metode penelitian kualitatif. Hasil penelitian menunjukkan bahwa Kementrian Perhubungan telah menggunakan media baru untuk pelayanan informasi publik yang memenuhi fungsi penyediaan informasi, pemberiaan informasi berdasarkan permintaan dan penampung aspirasi masyarakat.

Perbedaan penelitian tersebut membahas mengenai fenomena new media atau media baru yang dimanfaatkan oleh lembaga pemerintahan sebagai wujud pelayanan informasi publik. Dalam penelitian tersebut, penulis lebih memaparkan bagaimana pemanfaatan website dan sosial media sebagai wujud pelayanan informasi publik. Persamaan antara penelitian terdahulu dengan penelitian ini adalah metode penelitian yang digunakan, sama-sama menggunakan metode penelitian kualitatif. Kemudian, dalam pengamatan kamipun selain penggunaan metode yang sama, juga objek penelitiannya, yaitu merupakan bagian dalam lembaga pemerintahan yang berusaha meningkatkan pelayanan informasi publik.

Penelitian kedua yaitu Belinda Devi Larasati Siswanto dan Firda Zulivia Abraham (2016) berjudul "Peran Humas Pemerintah Sebagai Fasilitator Komunikasi Pada Biro Humas Pemprov Kalimantan Selatan". Penelitiannya dilakukan untuk mencari peran fasilitator komunikasi untuk memberikan informasi kepada masyarakat dan sebaliknya. Metode penelitian yang digunakan adalah metode penelitian kualitatif dengan studi kasus yang dikupas secara deskriptif. Hasil penelitian menunjukkan peran fasilitator komunikasi pada biro humas tidak maksimal, ketidaktersediaan informasi yang dapat di akses oleh publik menjadi penyebab tidak maksimalnya peran humas sebagai fasilitator komunikasi dari masyarakat ke pemerintah, maupun sebaliknya.

Perbedaan dengan penelitian terdahulu terletak pada fokus penelitiannya, karena penelitian terdahulu menekankan tentang peran humas sebagai fasilitator, sedangkan penulis lebih berfokus pada penggunaan media online sebagai sarana pendukung kerja digital public relations. Persamaan dengan penelitian terdahulu adalah sama-sama menggunakan metode penelitian kualitatif dengan teknik pengumpulan data melalui wawancara.

Tujuan penelitian ini adalah ingin mengetahui bagaimana implementasi penggunaan media online oleh public relations politik di lingkungan Pemprov DKI Jakarta dalam membantu tugas-tugas kerja Gubernur Anies Baswedan.

Penelitian ini menggunkan desain penelitian deskriptif eksploratif untuk mengurai data melalui analisis tindakan atau perilaku public relations secara menyeluruh. Data yang didapat dijelaskan dengan deskripsi secara 
komprehensif dengan basis data yang diperoleh dari wawancara dengan humas Pemprov DKI Jakarta.

\section{METODOLOGI}

Pendekatan penelitian yang peneliti gunakan adalah kualitatif. Penelitian kualitatif adalah penelitian yang digunakan untuk meneliti pada kondisi objek yang alamiah, (sebagai lawannya adalah eksperimen) dimana peneliti adalah sebagai instrumen kunci, teknik pengumpulan data dilakukan secara tringulasi (gabungan), analisa data bersifat induktif, dan hasil penelitian kualitatif menekankan makna dari pada generalisasi (Sugiyono, 2008:15)

Jenis penelitian ini adalah studi kasus deskriptif dengan pendekatan kualitatif pada Biro Humas Pemerintah Provinsi DKI Jakarta sebagai public relations politik yang menggunakan media online untuk melaksanakan tugas-tugasnya secara digital. Penelitian kualitatif diharapkan mampu menghasilkan uraian yang mendalam tentang ucapan, tulisan dan perilaku yang dapat diamati dari suatu individu, kelompok, masyarakat, dan atau organisasi tertentu dalam suatu keadaan konteks tertentu yang dikaji dari sudut pandang yang utuh, komperhensif, dan holistik (Sujarwandi, 2014:6).

Metode penelitin yaitu studi kasus deskriptif dalam penelitian ini juga bersifat eksploratif yang berangkat dari keinginan peneliti untuk melakukan penelusuran serta ingin mendapatkan ide-ide pokok dan memahami suatu sistem kerja (Moleong, 2016).

Lokasi penelitian di kantor Dinas Komunikasi, Informatika, dan Statistik Provinsi DKI Jakarta, Jalan Medan Merdeka Selatan No. 8-9 Blok G Lantai 13 Jakarta Pusat 10110 pada periode bulan maret tahun 2020 . Teknik pengumpulan data pertama yakni dengan wawancara mendalam menggunakan wawancara semi terstruktur. Pengumplan data kedua observasi, dilakukan untuk mengamati website diskominfotik.jakarta.go.id kemudian website ppid.jakarta.go.id yang pengelolaannya menjadi tanggung jawab Biro Humas DKI Jakarta. Selanjutnya yaitu dokumentasi. Dalam penelitian ini, data dokumentasi yang dicari berasal dari dua sumber, yaitu dari dalam internal Biro Humas dan dari eksternal Biro Humas. Kategori dokumen berupa pelayanan informasi publik, agenda, dan artikel dari media massa. Teknik pengumpulan data merupakan langkah yang paling utama dalam penelitian, karena tujuan utama dari penelitian adalah mendapatkan data (Sugiyono, 2008:308).

Sesuai dengan data yang didapat berdasarkan sumbernya yang telah dijabarkan sebelumnya, maka teknik pengumpulan data dalam penelitian ini, yaitu wawancara. Wawancara adalah bentuk komunikasi antara dua orang, melibatkan seseorang yang ingin memperoleh informasi dari seseorang lainnya dengan mengajukan pertanyaan-pertanyaan bedasarkan tujuan tertentu. Demikian juga dengan penelitian ini yang menggunakan wawancara dengan cara mengajukan pertanyaan-pertanyaan (Mulyana, 2003:181).

Observasi merupakan teknik pengumpulan data, dimana peneliti melakukan pengamatan secara langsung ke objek penelitian untuk melihat dari dekat kegiatan yang dilakukan (Riduwan, 2004:104).Studi pustaka berkaitan dengan kajian teoritis dan referensi lain yang berkaitan dengan nilai, budaya dan norma yang berkembang pada situasi sosial yang diteliti, selain itu studi pustaka sangat penting dalam melakukan penelitian, hal ini dikarenakan penelitian tidak akan lepas dari literatur-literatur ilmiah (Sugiyono, 2016:291).

Teknik penyajian data dilakukan dengan cara penguraian dalam deskripsi katakata (naratif) dan juga disajikan data formal berupa tabel kegiatan atau aktivitas humas. Penelitian ini memiliki sejumlah batasan. Berdasarkan ruang lingkupnya, penelitian ini hanya mengkaji pengunaan media online dan kerja digital public relations politik di lingkungan Pemerintah Provinsi DKI Jakarta saja. Analisis peran public relations yang digunakan dalam penelitian ini hanya memotret peran public relations politik di Provinsi DKI 
dengan dimensi peran dan maknanya yang sudah ditetapkan dalam konsep penelitian.

\section{HASIL DAN PEMBAHASAN}

Pelaksanaan tugas kerja public relations di Pemprov DKI Jakarta meliputi tugas-tugas pokok dan fungsinya yang menjadi satu kesatuan yang tertuang dalam Peraturan Gubernur (Pergub) Nomor 75 Tahun 2018 tentang perubahan atas Peraturan Gubenur Nomor 265 Tahun 2016 tentang Organisasi dan Tata Kerja Dinas Komunikasi, Informasi, dan Statistik. Kepala Seksi Informasi dan Komunikasi Publik, Koharudin menuturkan Diskominfotik DKI Jakarta memiliki tugas pokok dan fungsi sesuai Pasal 3 pada Pergub tersebut, yaitu secara umum Diskominfotik DKI Jakarta memiliki tugas melaksanakan urusan pemerintah bidang komunikasi dan informatika, statistik, dan persandian (Pasal 3 ayat 1) adapun mengenai fungsi Diskominfotik tertuang pada Pasal 3 ayat 2 Peraturan Gubernur.

Tugas pokok dan fungsi Diskominfotik DKI Jakarta sejalan dengan definisi konsepkonsep public relations. Konsep-konsep public relations memiliki kesamaan antara konsep satu dengan yang lainnya, kesamaan itu adalah sebagai berikut: Pertama, public relations itu sendiri adalah fungsi manajemen; Kedua, public relations adalah manajemen komunikasi antara organisasi dan publiknya; Ketiga, hubungan antara organisasi dan publik; Keempat, hubungan antara organisasi dan publiknya tersebut bersifat mutually beneficial.

Peneliti menemukan bahwa public realations Diskominfotik DKI melaksanakan fungsi manajemen untuk mengelola informasi sesuai undang-undang dan public realations DKI juga menjalankan tugasnya sebagai pelayan informasi antara organisasi dan publik. Pada pelaksanaan tugas pokok dan fungsi sebagai public relations di Pemprov DKI yang salah satu fungsinya yaitu menjalankan pengelolaan dan pelayanan informasi publik, tentu saja Diskominfotik butuh melibatkan media untuk membantu kelancaran dan penyebaran informasi kepada masyarakat.
Koharudin dalam keterangannya menyampaikan, media relations merupakan salah satu fungsi Diskominfotik DKI Jakarta sesuai dengan yang tertuang pada Pasal 3 Ayat 2 Poin J di Pergub Nomor 75 Tahun 2018 yang berbunyi Diskominfotik memiliki fungsi pelaksanaan layanan hubungan media. Pelaksaan media relations di implementasikan ke dalam satuan kerja bersama seksi pelayanan hubungan media dibawah koordinasi bidang komunikasi publik. Media relations menjadi instrumen penting dan signifikan untuk membantu kerja public realations di era keterbukaan informasi. "Di era keterbukaan informasi, maka fungsi Media (Press) relations menjadi penting dan signifikan untuk dilakukan sebagaimana amanat dari UUD Tahun 1945 Pasal 28F, UU Nomor 40 Tahun 1999 tentang Pers, dan UU Nomor 14 Tahun 2008 tentang keterbukaan informasi publik (KIP).

Lebih lanjut, Koharudin menyampaikan, Diskominfotik DKI Jakarta berkewajiban untuk mewujudkan kemerdekaan pers yaitu memperoleh serta menyebarluaskan gagasan dan informasi (UU Pers Pasal 4 Ayat 3), terkecuali informasi yang bersifat rahasia sesuai dengan undang-undang, kepatutan, dan kepentingan umum didasarkan pada pengujian tentang konsekuensi yang timbul apabila suatu informasi diberikan kepada masyarakat serta setelah dipertimbangkan dengan saksama bahwa menutup informasi publik dapat melindungi kepentingan yang lebih besar daripada membukanya atau sebaliknya (UU KIP Pasal 2 Ayat 4).

Melalui pernyataan yang disampaikan Kepala Seksi Informasi dan Komunikasi Publik, Koharudin, bahwa public relations Pemprov DKI Jakarta dipandang sangat perlu membangun media relations untuk menyampaikan berita kepada publik sesuai dengan aturan perundangan-undangan yang berlaku dan di era keterbukaan publik pers dianggap penting dalam menyelenggarakan aktivitas public relations dilingkungan Pemprov DKI Jakarta, meskipun di dalam undang-undang juga turut diatur ada informasi- 
informasi yang tidak dapat disampaikan kepada khalayak karena sifatnya yang rahasia.

Kerjasama public relations di Pemerintah Provinsi DKI Jakarta dengan media massa tidak hanya sekedar normatif dan retorik saja, tapi juga diikuti dengan kerja konkrit untuk membuka akses seluas-luasnya kepada media. Untuk itu, beragam kegiatanpun dilaksanakan oleh public relations demi kelancaran tugas jurnalistik di lingkungan balaikota Jakarta. Koharudin memaparkan ada dua macam metode yang digunakan untuk melayani wartawan yaitu dengan kegiatan non formal dan formal, yaitu: (1) Non formal, media gathering antara insan media bersama Gubernur DKI hingga SKPD Diskominfotik DKI, coffee morning antara insan media bersama SKPD Diskominfotik DKI, in depth interview antara Gubernur DKI dengan insan media misalnya dengan Tempo saat membahas KUA PPAS, buka puasa bersama Pemred dengan Gubernur DKI di rumah dinas, hingga pelibatan dalam advertorial tahunan; (2) Formal, konferensi pers tentang isu terkini langsung yang disampaikan oleh Gubernur DKI secara umum di balairung, media update tentang kerja SKPD yang termuat dalam Kegiatan Strategis Daerah (KSD) disampaikan oleh SKPD terkait secara mendalam di Blok F Lantai 2, publikasi rilis pasca kegiatan yang dimuat di PPID untuk ditulis ulang menjadi berita oleh insan media, penggunaan media sosial seperti instagram, twitter, hingga youtube bentuk siaran live dan tunda di youtube Pemprov DKI Jakarta tentang konferensi pers dan kegiatan rapat.

Pada poin kedua kegiatan formal yang dilakukan public relations Pemprov DKI disebutkan bahwa konferensi pers terkait isu terkini dilangsungkan tidak hanya dengan tatap muka saja, tetapi juga disampaikan menggunakan media online atau media baru seperti instagram, twitter, hingga youtube dengan format siaran langsung dan tunda di youtube Pemprov DKI Jakarta. Tentu dalam hal ini penulis menyimpulkan, public relations Pemprov DKI Jakarta telah menggunakan dan beradaptasi seiring perkembangan teknologi dengan menggunakan media baru sebagai sarana penunjang penyampaikan informasi kepada publik. Era informasi yang berkembang membuat public relations Pemprov DKI pun ikut mengembangkan diri sesuai kemajuan teknologi. Media baru pun dimanfaatkan secara baik sebagai alat untuk menjangkau khalayak yang lebih luas lagi.

Pemanfaatan media baru untuk menyebarkan informasi sejalan dengan karakteristik media baru yang dapat diakses secara global dan efisien. Koharudin menyatakan, sesuai UU Nomor 14 Tahun 2008 tentang Keterbukaan Informasi Publik Pasal 2 Ayat 3 disebutkan bahwa informasi publik yang dapat di akses harus cepat dan tepat waktu, biaya ringan dan sederhana. Selain untuk memudahkan masyarakat dalam memperoleh informasi, website milik pemprov DKI pun bisa memudahkan kerja wartawan, untuk itu disediakanlah laman http://ppid.jakarta.go.id/.sebagai implementasi pihak public relations Pemprov DKI Jakarta untuk memudahkan wartawan mendapatkan segala jenis press rilis resmi Pemprov DKI Jakarta yang selalu diperbaharui tiap harinya dan ditampilkan secara gadget-friendly, ditampilkan bersama dengan foto kegiatan.

Pelayanan akses informasi oleh public relations pemprov DKI untuk wartawan dilakukan secara menyeluruh melalui media baru milik pemprov DKI yang memuat konten kegiatan Gubernur hingga jajaran kelurahan di DKI. Koharudin menjelaskan "akses terhadap wartawan juga semakin di permudah dengan updating kegiatan mulai dari level gubernur hingga jajaran kelurahan di DKI Jakarta yang ditampilkan di media sosial masing-masing (facebook, instagram, twitter, hingga youtube) setiap harinya".

Koharudin menambahkan, jika terjadi situasi krisis, maka public relations Pemprov DKI Jakarta menyusun microsite baru dengan domain jakarta.go.id untuk memudahkan insan media mendapatkan informasi yang utuh, ditunjang dengan data-data memadai dan bersifat satu pintu. Hal ini seperti yang terimplementasikan pada laman 
https://corona.jakarta.go.id/id dalam memberikan informasi satu pintu yang dipebaharui tiap saatnya.

Berita yang berkaitan dengan Gubernur adalah yang paling ditanya oleh wartawan, biasanya seorang wartawan mencari pernyataan dari gubernur terkait isu yang sedang berkembang. "Informasi yang paling sering dan banyak diminta wartawan adalah yang berkaitan dengan pernyataan dari gubernur maupun SKPD terkait isu setiap harinya. Wartawan ingin mengolah informasi, setiap informasi yang didapat untuk dijadikan pemberitaan, baik untuk daring, cetak, maupun televise (led by issue)", kata Koharudin.

Selain itu, informasi yang menarik bagi wartawan di Pemprov DKI Jakarta adalah tema yang berkaitan dengan realisasi janji kampanye, khususnya menyentuh langsung kepemenuhan kebutuhan dasar masyarakat. Misalnya, Program hunian samawa DP 0 Rupiah, KJP Plus, integrasi transporasi, dan sebagainya (creating issue).

Gubernur DKI merupakan yang paling berwenang menjawab pertanyaan dari wartawan, sesuai Undang-Undang Nomor 40 Tahun 1999, gubernur memiliki hak jawab dan hak koreksi. Namun, bukan tidak mungkin pihak lain di lingkungan Pemprov DKI Jakarta pun bisa ikut membantu menjawab pertanyaan dari wartawan. Koharudin menjelaskan, kewenangan itu bisa diambil jika gubernur mendelegasikan kewenangan tersebut kepada SKPD atau jajaran terkait untuk menjelaskan secara lebih rinci dan komprehensif kepada wartawan. "Oleh karena itu, jika wartawan membutuhkan informasi terkait isu terkini, dapat menanyakan terlebih dahulu kepada Tim Gubernur untuk kapan dan dalam momen apa gubernur memiliki kesempatan menjelaskan hal tersebut. Tim Gubernur yang akan menjembatani sekaligus untuk menentukan apakah informasi tersebut dijawab langsung oleh gubernur atau bisa didelegasikan ke SKPD atau jajaran terkait".

Lebih lanjut Koharudin menuturkan, kedepan wartawan yang meliput di balai kota akan dilengkapi dengan ID pers khusus,
"Updating nama-nama insan media Pemprov DKI Jakarta terus dilakukan setiap 6 bulan sekali, dan kedepan akan dipertimbangkan ID khusus para wartawan yang bertugas di balaikota dan surat penugasan dari masingmasing kantor berita. Dengan hal ini, public relations Pemprov DKI Jakarta dapat lebih mudah melakukan koordinasi lebih intensif dan dekat baik formal maupun informal.

Tanggapan masyarakat terhadap kinerja Pemprov DKI tidak selalu baik, karena setiap kebijakan tidak dapat menyenangkan semua pihak. Kritik pun kerap datang dari mereka yang kontra pada kebijakan, namun pihak Pemprov DKI harus memperlakukan pujian dan kritik secara egaliter. Karena, setiap kritik yang datang bisa saja membuat kinerja jauh lebih baik.

Koharudin menyebut setiap pemberitaan positif ataupun negatif perlu disikapi dengan rasa penuh tanggung jawab, karena berpendapat merupakan hak warga di dalam negara yang demokratis dan diatur serta dijamin pelaksanaannya di dalam undang-undang. "Sehingga dalam iklim negara demokrasi yang sesuai dengan prinsip Pancasila dan UUD di atas, maka Pemprov DKI menilai setiap pemberitaan adalah bagian dari perwujudan hak konstitusi setiap warga negara yang harus dilindungi dan dilakukan secara bertanggungjawab, apapun tone dari pemberitaan tersebut".

Meski demikian, Koharudin menambahkan, wartawan dalam melaksanakan kerja jurnalistik perlu mengedepankan normanorma dan kode etik jurnalistik. Jadi, wartawan harus senantiasa berimbang, akurat serta tidak sengaja membuat pemberitaan buruk tanpa memiliki data dan fakta yang memadai, selain itu wartawan juga harus menyediakan ruang klarifikasi untuk sebuah pernyataan terkait isu atau berita negatif yang beririsan dengan Pemprov DKI. "Meskipun demikian, dalam UU Pers Nomor 40 tahun 1999 Pasal 5 juga disebutkan bahwa wartawan mengedepankan norma-norma agama dan rasa kesusilaan di masyarakat serta asas praduga tak bersalah. Selain itu, dalam Kode Etik Jurnalistik (Pasal 1) 
disebutkan "Wartawan Indonesia bersikap independent menghasilkan berita yang akurat, berimbang, dan tidak berita buruk".

Koharudin menegaskan, Dari dua ketentuan di atas, Pemprov DKI Jakarta menghormati setiap pemberitaan, termasuk pemberitaan negatif (negative campaign) sepanjang dilakukan secara berimbang dalam rangka kontrol sosial, dan tidak mengarah kepada fitnah dan hoaks (black campaign). Negative Campaign dimaksudkan berita tersebut benar namun tidak tepat dari sisi sosial kemasyarakatan sehingga perlu dilakukan kontrol sosial. Sedangkan Black Campaign berarti berita tersebut tidak benar, hoaks, dan fitnah sehingga wartawan tersebut dapat dikategorikan melanggar Kode Etik Jurnalistik dan UU Nomor 40 Tahun 1999 tentang Pers.

Koharudin memandang hambatanhambatan di dalam media relations sebagai tantangan yang harus dijalankan karena proses membangun komunikasi politik ini juga kian memiliki tantangan bukan hambatan di saat setiap insan wartawan sekaligus juga adalah bagian dari Perusahaan Pers yang memiliki sikap redaksi dan nilai pemberitaan masingmasing. Meskipun demikian, public relations Pemprov DKI Jakarta selalu mendudukan media sebagai mitra kerja yang menjadi tempat bertukar pikiran/gagasan sekaligus kontrol sosial dalam rangka check and balances." public relations Pemprov DKI Jakarta memiliki dua infrastruktur untuk mendukung kinerja. Pertama, infrastruktur yang didukung dari personil tenaga Aparatur Sipil Negara (ASN); Kedua, infrastruktur yang didukung dari personil tenaga terampil tenaga ahli profesional non-ASN".

Para ASN di public relations Pemprov DKI Jakarta ini yang mengeksekusi kebijakan (operator) atas arahan dari Gubernur DKI melalui Tim Gubernur. Para ASN di public relations Pemprov DKI Jakarta ini sekaligus mengelola sumber daya manusia para tenaga ahli profesional tersebut, mulai dari jadwal kerja, rekruitmen, hingga alat-alat penunjang kinerja teknis selama liputan baik di kantor maupun di lapangan. Sedangkan, para tenaga ahli professional memiliki tugas untuk melakukan dokumentasi kegiatan gubernur, wakil gubernur, dan SKPD di lingkungan Pemprov DKI Jakarta, khususnya yang terangkum dalam agenda Kegiatan Strategis Daerah (KSD) di tiap bulannya. Pembagian kerja tenaga ahli profesional, terbagi kedalam beberapa penugasan yaitu, Operator Media Sosial, Reporter, Kameramen, Fotografer, Editor Foto, Data Entry, dan Editor Video.

\section{SIMPULAN}

Public relations Pemprov DKI memanfaatkan media baru seperti website, facebook, dan twitter sebagai sarana penunjang penyebaran informasi kepada masyarakat. Selain itu, media online digunakan sebagai alat komunikasi dua arah antara Pemprov DKI dan masyarakat. Penggunaan media baru dapat membantu kerjakerja digital public relations di Pemprov DKI, meskipun dalam penerapannya perlu dikembangkan lagi menjadi lebih kreatif. Public relations di Pemprov DKI juga memperkuat penyebaran arus informasi dengan membangun hubungan baik dengan media massa sebagai mitra strategis, dalam menunjang pekerjaanya, public relations mengacu pada peraturan perundang-undangan yang berlaku sebagai pedoman melaksanakan tugas-tugasnya sebagai pelayan informasi kepada masyarakat. Media relations yang dibangun oleh public relations Pemprov DKI Jakarta sejauh ini cukup efektif dan harmonis. Karena penggunaan media baru harus bersinergi dengan media massa agar penyebaran informasi dapat efektif, menyeluruh dan konsisten. Efektif dalam arti bahwa setiap kegiatan yang dimuat kedalam press rilis, diterima oleh insan media dengan baik dan dapat di kutip menjadi karya jurnalistik yang dapat dibaca oleh masyarakat. Dengan berbagai kodisi tersebut, secara tidak langsung public relations Pemprov DKI Jakarta sudah melakukan kerja-kerja public relations politik sesuai dengan utama dari public relations politik. Menurut data statistik di DKI Jakarta, memiliki awarness besar terhadap berbagai kanal digital yang 
disediakan. Meskipun, masih memerlukan kanal-kanal yang konvensional seperti aduan di kelurahan dan semacamnya.

\section{DAFTAR PUSTAKA}

Budiarjo, M. (2005). Dasar-Dasar Ilmu Politik. Jakarta: Gramedia Pustaka Utama.

Cutlip, Scott M., A. H. C. (2000). Effective Public Relations (Eight). New Jersey: Prentice Hall.

Heryanto, Gun Gun \& Zarkasi, I. (2012). Public Relations Politik. Bogor: Ghalia Indonesia.

Heryanto, G. G. (2018). Media Komunikasi Politik. Yogjakarta: Diva Press.

http://ppid.jakarta.go.id/. (n.d.).

https://diskominfotik.jakarta.go.id/bidangkomunikasi-publik,. (n.d.).

Lilleker, D. G. (2006). Key Concepts in Plitical Cmmunication. London: Thousand Oaks: Sage Publications.

Moleong, L. J. (2016). Metodologi Penelitian Kualitatif Edisi Revisi. Bandung: PT. Remaja Rosdakarya.

Morris, T. dan Goldsworthy, S. (2008). Public Relations For Asia (First, Ed.). New York: Palgrave Macmillan.

Mulyana, D. (2003). Ilmu Komunikasi : Suatu Pengantar. Bandung: PT. Remaja Rosdakarya.

Natawilaga, S. (2018). Peran Etika Dalam Meningkatkan Eefektifitas Pelaksanaan Public Relations. WACANA, Jurnal Ilmiah
Ilmu Komunikasi, 17(1), 64. https://doi.org/10.32509/wacana.v17i1.49 2

Riduwan. (2004). Metode dan Teknik Menyusun Tesis. Bandung: Alfabeta.

Romli, A. S. M. (2012). Jurnalistik Online: Panduan Mengelola Media Online. Bandung: Nuansa Cendikia.

Rusfian, Effy \& Nuhajati, L. (2015). Political Public Relations Dalam Media Sosial (Kajian Teoritis dan Implementasinya untuk Kandidat Politik). Jakarta: UI Press.

Strömbäck, J. \& K. (2011). Political Public Relations, Principles and Applications. New York: Routledge.

Sugiyono. (2008). Metode Penelitian Kuantitatif Kualitatif dan $R \& D$. Bandung: Alfabeta.

Sugiyono. (2016). Memahami Penelitian Kualitatif. Bandung: Alfabeta. https://doi.org/10.1111/j.13652036.2009.03946.x

Sujarwandi, V. . (2014). Metodologi Penelitian. Yogjakarta: Pustaka Baru Press.

West, R., \& Turner, L. H. (2008). Introducing Communication Theory: Analysis and Aplication. In McGraw Hill- High Education (Four). https://doi.org/10.4324/978135113012713 